\title{
Hidden structural heterogeneity enhances marine hotspots' biodiversity
}

\author{
Georgios Kazanidis $^{1}\left(\mathbb{D} \cdot\right.$ Lea-Anne Henry $^{1} \cdot$ J. Murray Roberts $^{1}$
}

Received: 10 January 2021 / Accepted: 12 May 2021/Published online: 14 July 2021

(C) The Author(s) 2021

\begin{abstract}
Studies in terrestrial and shallow-water ecosystems have unravelled the key role of interspecific interactions in enhancing biodiversity, but important knowledge gaps persist for the deep sea. Cold-water coral reefs are hotspots of biodiversity, but the role of interspecific interactions and "habitat cascades" (i.e. positive effects on focal organisms mediated by biogenic habitat formation) in shaping their biodiversity is unknown. Associations between macrofaunal hosts and epifauna were examined in 47 stations at the Mingulay Reef Complex (northeast Atlantic). In total, 101 (group level) and 340 (species level) unique types of facultative associations formed by 43 hosts and 39 epifaunal species were found. Molluscs and empty polychaete tubes had higher values for the type and number of host-epifaunal associations, the Shannon-Wiener $(H)$ and Margalef (d) indices of the epifauna than the rest of the taxonomic groups $(p<0.05)$. Hosts' body size, orientation, surface smoothness, and growth form explained a significant amount of variability (32.96\%) in epifauna community composition. Epifaunal species richness $(S)$, $H$ and $d$ were $27.4( \pm 2.2 \%), 56.2( \pm 2.8 \%)$ and 39.9 $( \pm 2.3 \%)$ of the respective values for the total sessile communities living on coral framework. This is intriguing as coral framework is orders of magnitude larger than the size of macrofaunal hosts. It is suggested that bivalves, tunicates and empty polychaete tubes increase habitat heterogeneity and enhance biodiversity through "habitat
\end{abstract}

Topic Editor Alastair Harborne

Georgios Kazanidis

gkazanidis@gmail.com

1 Changing Oceans Group, School of GeoSciences, Grant Institute, University of Edinburgh, Kings Buildings, James Hutton Road, Edinburgh EH9 3FE, UK cascades", in a similar way that epiphytes do in tropical rainforests. Most macrofaunal habitat suppliers in the studied cold-water coral reef are calcified species and likely susceptible to ocean acidification. This indicates that the impacts of climate change on the total biodiversity, structure and health of cold-water coral reefs may potentially be more severe than previously thought.

Keywords Macrofauna - Symbiosis - Biodiversity hotspots $\cdot$ Deep sea $\cdot$ Cold-water coral reefs

\section{Introduction}

Unravelling the mechanisms that drive the formation of hotspots of species biodiversity is a critical component for the understanding of their structure and functioning. Studies in terrestrial, and aquatic ecosystems have shown the importance of stable environmental conditions over geological time scales (e.g. ancient rivers and lakesBolotov et al. 2017), energy availability (e.g. tropical forests-Sullivan et al. 2017), multiple macroevolutionary routes (Igea and Tanentzap 2019) and habitat heterogeneity in shaping hot spots of biodiversity (e.g. in springsCantonati et al. 2012; rocky seaweed forests; Thomsen et al. 2010; tropical rain forests-Nakamura et al. 2017).

Evidence from relatively well-studied ecosystems such as tropical rain forests, kelp forests and sandy seagrass beds served the unravelling of "habitat cascades" phenomenon and its role in ecosystem biodiversity (Thomsen et al. 2010). Habitat cascades occur when there are indirect positive effects on focal organisms mediated by successive biogenic formation or habitat modification. They are a general phenomenon that enhances species abundance and diversity (Thomsen et al. 2010). For example, the highest 
biodiversity in rainforests is often found within the canopy, which is formed by overlapping tree branches and leaves; therein, primary epiphytes (e.g. vascular bromeliads) increase habitat heterogeneity and biodiversity of focal organisms (Nakamura et al. 2017).

Being the largest biome on Earth, the deep sea (typically $>200 \mathrm{~m}$ water depth) remains still the least explored. Technological progress, however, over the last thirty years has facilitated the discovery of deep-sea biodiversity hotspots such as reefs formed by scleractinian cold-water corals (CWCRs hereafter; Roberts et al. 2006; Cordes et al. 2021), gorgonian coral forests and similar CWC non-reef environments (Angiolillo and Canese 2017; Li and Wang 2019). These are also hotspots of biomass, carbon cycling and ecosystem services (Cathalot et al. 2015; Henry and Roberts 2017). Patterns in CWCRs biodiversity are related to seafloor bathymetry, hydrography, life histories of the fauna themselves (Henry et al. 2013) as well as to substrate availability/type (Bourque and Demopoulos 2018), food supply (Kazanidis and Witte 2016), social interactions (e.g. foraging, mating) and dispersal (Henry et al. 2013).

Important knowledge gaps remain for CWCR biodiversity and particularly interspecific interactions. For example, are habitat cascades present in CWCRs and if yes, what is their role in biodiversity and how does climate change stand to alter this? Are the relationships between hosts and epifauna facultative or obligate? Are there any common features among habitat suppliers, e.g. are they calcified or non-calcified? Studies on megafaunal hosts have shown facultative relationships with their epifauna (Buhl-Mortensen and Mortensen 2004a) and parasitism (Carreiro-Silva et al. 2017), but almost nothing is known for macrofauna $(500 \mu \mathrm{m}-5 \mathrm{~cm}$ body length; Gage and Tyler 1991). This is an important knowledge gap as macrofauna are key components in ecosystem functioning: they are extremely species rich (Grassle and Maciolek 1992) and shape benthic elemental cycling (Janas et al. 2019). In CWCRs macrofauna are speciose exceeding by far megafauna species richness (Henry and Roberts 2017). Macrofauna species have also several morphotypes (e.g. erect, horizontal), body texture (soft or calcified) and external morphology (smooth or spiny body surfaces). This high morphotype diversity combined with high macrofaunal density and biomass (Kazanidis and Witte 2016) create many microhabitats and possibly enhance biodiversity, similarly to epiphytes in tropical forests (Nakamura et al. 2017).

Advancing knowledge about the role of macrofauna in ecosystem functioning is crucial for one more reason. Models predict large-scale shifts in water-mass characteristics by 2100 (e.g. pH reduction by 0.37 units; Puerta et al. 2020) which in turn will have negative impacts on the distribution (Morato et al. 2020) and skeletal integrity of habitat-forming cold-water corals (Hennige et al. 2020). These are expected to damage the role of these corals in supporting high biodiversity (Henry and Roberts 2017) and their overall health and environmental status (Kazanidis et al. 2020; Morato et al. 2020). Thus, unravelling (1) the role of macrofauna as habitat suppliers and (2) the features of these species are key things for understanding CWCR sensitivity to climate change. This is especially true for calcified macrofauna as they are expected to be more sensitive to ocean acidification than the non-calcified macrofaunal species (Bell et al. 2018; Byrne and Fitzer 2019). In the present study, macrofaunal communities from a well-studied CWCR, the Mingulay Reef Complex (MRC, hereafter) in the northeastern Atlantic were examined with the aim of unravelling their contributions to CWCR heterogeneity and biodiversity.

\section{Materials and methods}

\section{Study area}

The MRC is located in the Outer Hebrides Sea, western Scotland (Roberts et al. 2005). Since its discovery in 2003 (Roberts et al. 2005) the MRC has been one of the best studied CWCRs in the world in terms of its bathymetry, hydrography, ecosystem functioning and biodiversity (e.g. Roberts et al. 2009; Henry et al., 2013; De Clippele et al. 2021 and references therein).

Habitat mapping has shown that the MRC's mounded bathymetry was formed by reefs of the scleractinian coldwater coral Lophelia pertusa (Roberts et al. 2005). Specifically, surveys using multibeam echosounders and seabed video revealed $L$. pertusa mounds in 5 areas: MRC1, Banana Reef, MRC 5 North, MRC 5 South and Four Mounds (Roberts et al. 2009; Duineveld et al. 2012; Fig. 1). The mounds are 13-60 m wide, 16-108 $\mathrm{m}$ long and between 2 and $34 \mathrm{~m}$ tall (De Clippele et al. 2017). Studies have shown that CWCR habitats are most well developed at MRC1, Banana Reef and MRC5 North (Roberts et al. 2009; Duineveld et al. 2012; Henry et al. 2013). Geochronology of vibrocore samples showed that Lophelia reefs have been present for at least 7000 years (Douarin et al. 2014, 2016).

MRC is primarily bathed by North Atlantic Water (10.0-10.5 ${ }^{\circ} \mathrm{C}, 35.4 \mathrm{psu}$ ) which flows onto the European shelf from the eastern subpolar North Atlantic (Johnson et al. 2013; Porter et al. 2018). Benthic lander and mooring deployments have shown that rapid downwelling transfers fresh microalgae to the MRC CWCR habitats (Davies et al. 2009; Duineveld et al. 2012). Integration of geophysical, hydrological and species life history traits unravelled that bathymetric and hydrographic gradients were important in 
shaping macrofaunal biodiversity across reefs, while within reefs, the assemblages were shaped by recruitment, food supply, foraging and mating interactions (Henry et al. 2010, 2013).

The MRC area is part of the East Mingulay Marine Protected Area and is fully closed to mobile bottom-tending fishing gear, to protect coral features and associated biodiversity (Roberts et al. 2009).

\section{Benthos}

Benthic samples for the examination of host-epifauna associations were available from 47 stations which were sampled in 2009, 2010 and 2011; 43 of these stations are found at MRC1 and four are found at Banana Reef, two of the most developed reefs at MRC (Fig. 1, Table 1). The stations have not been recurrently investigated in the three sampling periods (Table 1). The samples were collected using a modified Van Veen Grab (sampling $0.1 \mathrm{~m}^{2}$ per deployment), and most of them come from dead coral framework or a mixture of dead and live framework habitats (Fig. S1 in the Supplementary Material).

Samples were sieved at $1 \mathrm{~mm}$, macrofauna collected and stored in $4 \%$ seawater formalin and transferred to $70 \%$ industrial methylated spirit. Hosts and epifauna were identified to the lowest possible taxonomic level using best available taxonomic keys for North Atlantic marine invertebrates and guidance from expert taxonomists (Tables S1-S2 in the Supplementary Material).

The faunal groups that were investigated were the following: anthozoans, arthropods, brachiopods, bryozoans, echinoderms, entoprocts, molluscs, nemerteans, oligochaetes, platyhelminthes, polychaetes (including empty serpulid and eunicid tubes), priapulids, sipunculans, tunicates, and shark eggs. Following Henry et al. (2013), sponges were excluded due to a lack of taxonomic resolution. This exclusion should not be regarded as a deficiency as previous studies have shown that small-/mediumsized sponges at MRC host limited epi- and infaunal communities (Kazanidis et al. 2016).

Accounting for the existence of both colonial and solitary taxa, species' presence/absence was recorded. Data from all stations were compiled in a species assembly matrix using Primer v.7 (Clarke and Gorley 2015) to investigate possible differences among the communities colonizing the macrofaunal hosts (see below for details).

Macrofaunal host species' features considered in explaining variability in their epifaunal communities were (1) body size (A: 0-49 $\mathrm{mm}^{2}, \quad$ B: $50-99 \mathrm{~mm}^{2}$, $\mathrm{C}: \geq 100 \mathrm{~mm}^{2}$ ), (2) body texture (A: calcified, B: noncalcified), (3) body surface roughness (A: smooth, B: nonsmooth), (4) body orientation (A: horizontal, B: erect), (5) growth form (A: solitary, B: colonial) and (6) condition when collected (A: alive, B: dead) (Table S3).

\section{Data analysis}

Data in the species assembly matrix were used in the calculation of three biodiversity indices, i.e. species richness $(S)$, Shannon-Wiener $(H)$, Margalef (d) and total taxonomic distinctness $\left(\mathrm{S} \Delta^{+}\right)$. The species assembly matrix was also used to calculate Bray-Curtis similarities and similarity matrices (Clarke and Gorley 2015).

Based on these matrices, dendrograms using group average (Clarke and Gorley 2015) were constructed showing the clustering of the organisms [at the group (e.g. bivalves, bryozoans) and species levels] hosting epifauna. One-way analysis of similarities (ANOSIM) was carried
Fig. 1 a Location of the Mingulay Reef Complex (total area $\sim 100 \mathrm{~km}^{2}$ ) in the Sea of the Outer Hebrides (northeast Atlantic). b Locations of sampling stations at Mingulay Reef Complex 1 (MRC1) and Banana Reef (BR) are shown. Colour shading represents bathymetry, see legend. For more details on stations see Table 1
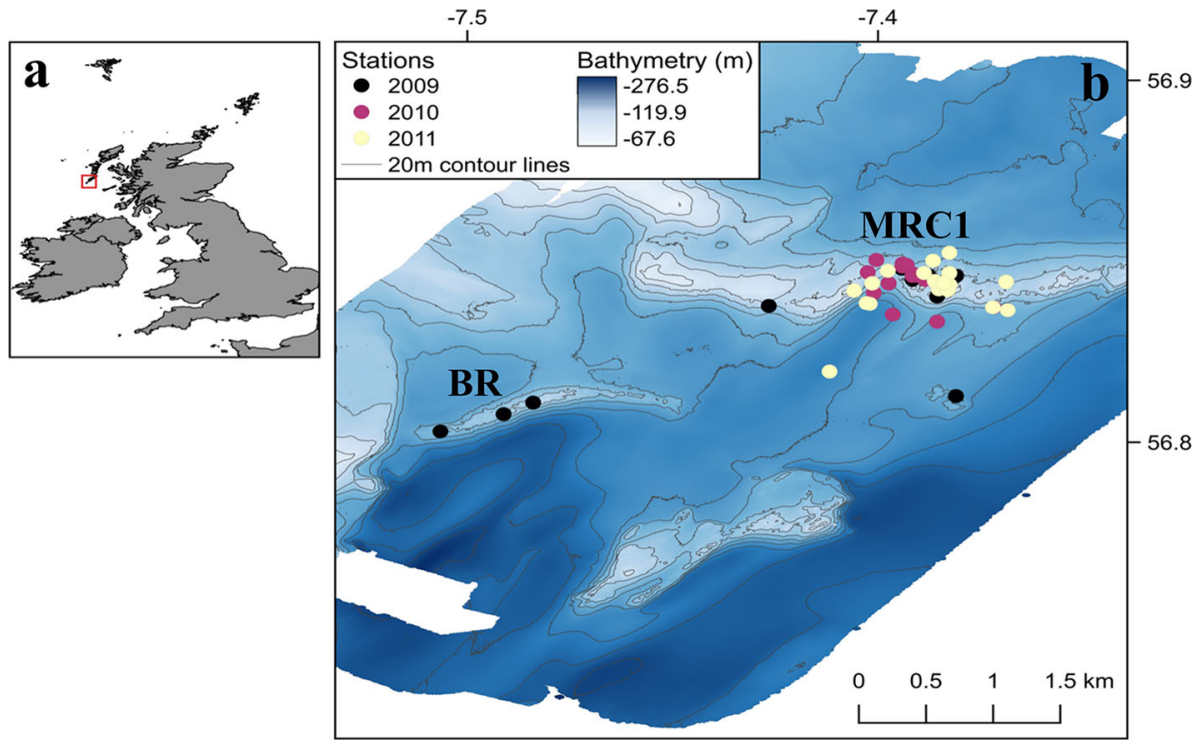
Table 1 Samples analysed for the examination of hosts and their epifauna at Mingulay Reef Complex 1 (MRC1) and Banana Reef (BR)

\begin{tabular}{|c|c|c|c|c|c|c|c|c|c|c|c|}
\hline Station code & Area & Year & $\begin{array}{l}\text { Water depth } \\
\text { (m) }\end{array}$ & Latitude & Longitude & Station code & Area & Year & $\begin{array}{l}\text { Water depth } \\
\text { (m) }\end{array}$ & Latitude & Longitude \\
\hline 1484 & MRC1 & 2009 & 133 & 56.8189 & -7.4133 & $\begin{array}{l}20100505 / \\
002\end{array}$ & MRC1 & 2010 & 151 & 56.8252 & -7.4002 \\
\hline 1485 & MRC1 & 2009 & 127 & 56.823 & -7.3905 & $\begin{array}{l}20100505 / \\
003\end{array}$ & MRC1 & 2010 & 135 & 56.8233 & -7.3957 \\
\hline 1486 & MRC1 & 2009 & 133 & 56.8231 & -7.3939 & $\begin{array}{l}20100505 / \\
004\end{array}$ & MRC1 & 2010 & 152 & 56.8243 & -7.39701 \\
\hline 1487 & $\mathrm{BR}$ & 2009 & 138 & 56.8039 & -7.4456 & $\begin{array}{l}\text { 20100505/ } \\
005\end{array}$ & MRC1 & 2010 & 152 & 56.8245 & -7.3965 \\
\hline 1488 & $\mathrm{BR}$ & 2009 & 118 & 56.8055 & -7.442 & $\begin{array}{l}20100505 / \\
006\end{array}$ & MRC1 & 2010 & 138 & 56.8177 & -7.3982 \\
\hline 1489 & BR & 2009 & 127 & 56.8064 & -7.3905 & $\begin{array}{l}20110608 / \\
003\end{array}$ & MRC1 & 2011 & 131 & 56.8212 & -7.3926 \\
\hline 1490 & $\mathrm{BR}$ & 2009 & 165 & 56.8015 & -7.4533 & $\begin{array}{l}20110608 / \\
004\end{array}$ & MRC1 & 2011 & 167 & 56.8183 & -7.3842 \\
\hline 1491 & MRC1 & 2009 & 108 & 56.8202 & -7.3928 & $\begin{array}{l}\text { 20110608/ } \\
005\end{array}$ & MRC1 & 2011 & 185 & 56.8192 & -7.401 \\
\hline 1492 & MRC1 & 2009 & 127 & 56.8228 & -7.3945 & $\begin{array}{l}20110608 / \\
007\end{array}$ & $\mathrm{MRC} 1$ & 2011 & 124 & 56.8187 & -7.386 \\
\hline 1494 & MRC1 & 2009 & 127 & 56.8229 & -7.395 & $\begin{array}{l}20110608 / \\
008\end{array}$ & MRC1 & 2011 & 164 & 56.8223 & -7.3931 \\
\hline 1495 & MRC1 & 2009 & 134 & 56.8232 & -7.3955 & $\begin{array}{l}20110608 / \\
009\end{array}$ & MRC1 & 2011 & 162 & 56.8218 & -7.3913 \\
\hline 1496 & MRC1 & 2009 & 125 & 56.8225 & -7.3958 & $\begin{array}{l}20110608 / \\
010\end{array}$ & MRC1 & 2011 & 153 & 56.8211 & -7.3915 \\
\hline 1498 & MRC1 & 2009 & 146 & 56.824 & -7.3971 & $\begin{array}{l}\text { 20110608/ } \\
011\end{array}$ & MRC1 & 2011 & 150 & 56.8234 & -7.3913 \\
\hline 1500 & MRC1 & 2009 & 131 & 56.823 & -7.395 & $\begin{array}{l}\text { 20110608/ } \\
012\end{array}$ & MRC1 & 2011 & 162 & 56.8221 & -7.392 \\
\hline $\begin{array}{l}20100223 / \\
002\end{array}$ & MRC1 & 2010 & 125 & 56.823 & -7.3958 & $\begin{array}{l}20110609 / \\
001\end{array}$ & MRC1 & 2011 & 142 & 56.8193 & -7.4014 \\
\hline $\begin{array}{l}20100223 / \\
003\end{array}$ & MRC1 & 2010 & 130 & 56.823 & -7.3951 & $\begin{array}{l}20110609 / \\
002\end{array}$ & MRC1 & 2011 & 162 & 56.8098 & -7.4059 \\
\hline $\begin{array}{l}20100223 / \\
004\end{array}$ & MRC1 & 2010 & 140 & 56.822 & -7.3928 & $\begin{array}{l}20110707 / \\
003\end{array}$ & MRC1 & 2011 & 169 & 56.8262 & -7.3913 \\
\hline $\begin{array}{l}20100223 / \\
005\end{array}$ & MRC1 & 2010 & 135 & 56.822 & -7.3987 & $\begin{array}{l}20110707 / \\
004\end{array}$ & MRC1 & 2011 & 135 & 56.822 & -7.4007 \\
\hline $\begin{array}{l}20100504 / \\
001\end{array}$ & $\mathrm{MRC} 1$ & 2010 & 190 & 56.8167 & -7.3928 & $\begin{array}{l}20110707 / \\
005\end{array}$ & MRC1 & 2011 & 121 & 56.821 & -7.4029 \\
\hline $\begin{array}{l}20100504 / \\
002\end{array}$ & MRC1 & 2010 & 156 & 56.8187 & -7.3859 & $\begin{array}{l}20110707 / \\
006\end{array}$ & MRC1 & 2011 & 154 & 56.8222 & -7.3844 \\
\hline $\begin{array}{l}20100504 / \\
003\end{array}$ & MRC1 & 2010 & 122 & 56.8235 & -7.40125 & $\begin{array}{l}20110707 / \\
008\end{array}$ & MRC1 & 2011 & 134 & 56.8237 & -7.3988 \\
\hline $\begin{array}{l}20100504 / \\
004\end{array}$ & MRC1 & 2010 & 171 & 56.8207 & -7.4005 & $\begin{array}{l}20110707 / \\
009\end{array}$ & MRC1 & 2011 & 159 & 56.8251 & -7.3933 \\
\hline $\begin{array}{l}20100504 / \\
005\end{array}$ & MRC1 & 2010 & 123 & 56.8225 & -7.3943 & $\begin{array}{l}20110707 / \\
010\end{array}$ & MRC1 & 2011 & 154 & 56.8234 & -7.3944 \\
\hline $\begin{array}{l}\text { 20100504/ } \\
008\end{array}$ & MRC1 & 2010 & 151 & 56.8247 & -7.397 & & & & & & \\
\hline
\end{tabular}

out to check for significant differences in the epifaunal communities hosted by each group (e.g. bivalves vs. bryozoans). Identifying the species that were responsible for the average dissimilarity between the groups was carried out by similarity percentage analysis (SIMPER) (Clarke and Gorley 2015). The identification of obligate and 
Fig. 2 Hosts and their epifauna. a Anthozoan of the family Actiniidae attached on an empty parchment-like eunicid tube; b the bryozoans Disporella hispida and Smittoidea reticulata attached on the brachiopod Novocrania anomala; $\mathbf{c}$ the brachiopod Eucalathis tuberata attached on the bivalve Hiatella arctica; d the bryozoan Amphiblestrum flemingii attached on a shark egg; e the bryozoan

Terminoflustra barleei on the erect bryozoan Omalosecosa ramulosa; $\mathbf{f}$ the anthozoan Parazoanthus anguicomus on the erect tunicate Polycarpa pomaria

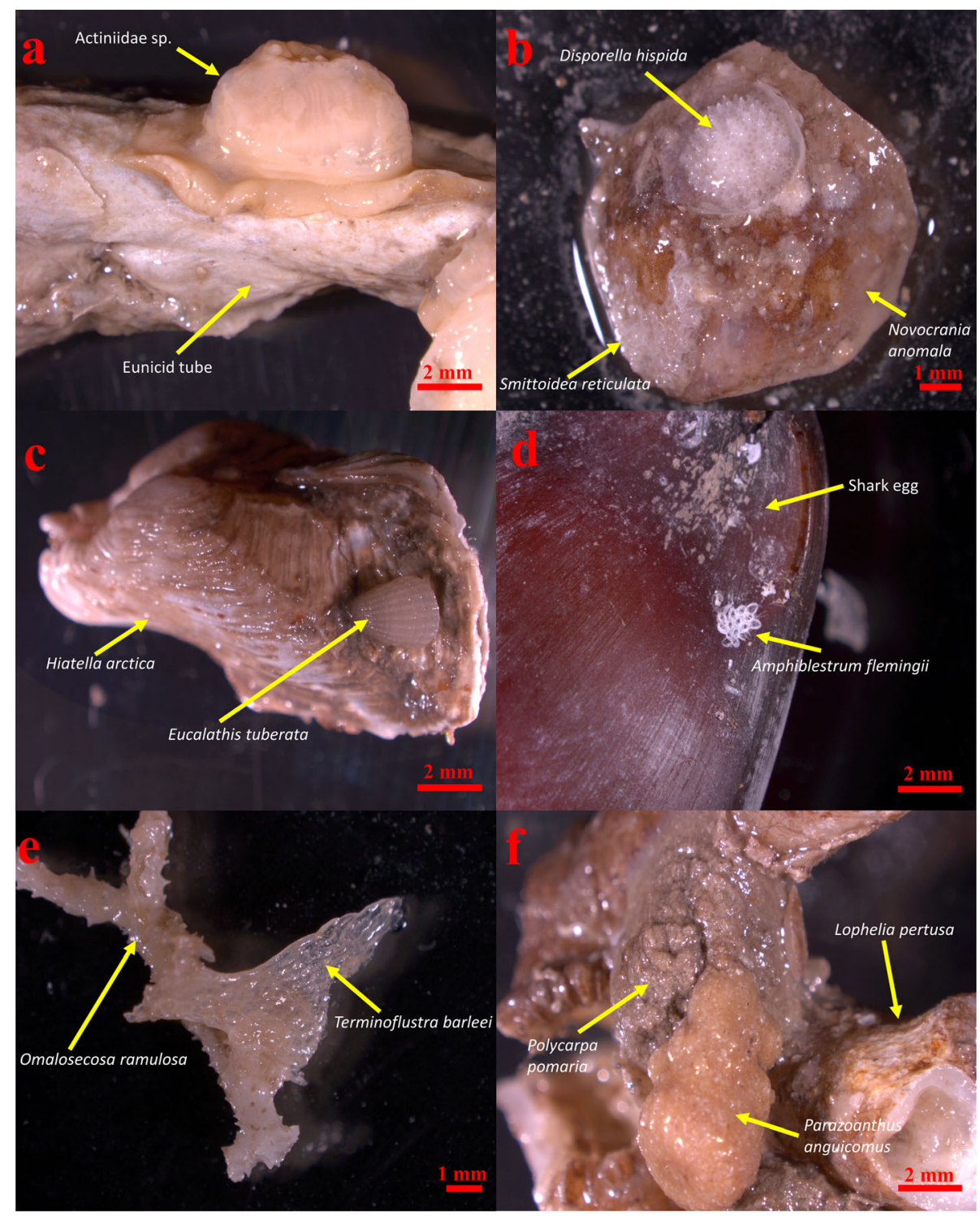

facultative symbionts was carried out following BuhlMortensen and Mortensen (2004a) where obligate ones were characterized as the symbionts found in association with only a single taxonomic group.

The presence of statistically significant differences across the groups in terms of (1) types of host-epifaunal associations (T), (2) number of host-epifaunal associations (N), (3) $H$ and (4) d in epifaunal communities, was examined in RStudio (rstatix package). The normality of the distributions was checked with the Shapiro-Wilk test and the equality of variances with the $F$-test (for two groups) or Bartlett test (for three groups). In the case of normal distribution and equal variances, the hypothesis that the groups have the same mean was tested either through the two-sample $t$-test (two groups) or one-way ANOVA (three groups). In the case of normal distributions and unequal variances, the hypothesis that the groups have the same mean was tested either through the Welch's twosample $t$-test (two groups) or one-way analysis of means (not assuming equal variances) (three groups). Finally, in the case of the normal distribution criterion did not hold, the hypothesis that the groups have the same median was tested either through a Wilcoxon rank sum test (two groups) or a Kruskal-Wallis rank sum test (three groups). These tests were followed by pairwise comparisons to examine for the presence of statistically significant differences in pairs of groups. In the case of one-way ANOVA, multiple comparisons were carried out through the Tukey's test. In the case of one-way analysis of means, the comparisons were carried out through the Games Howell test (Burk 2018). When the Kruskal-Wallis test was used, the pairwise comparisons were carried out through the Dunn 


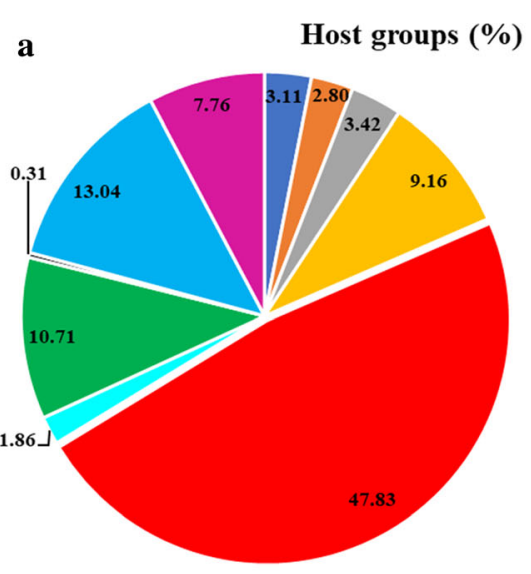

- Anthozoans

- Arthropods

- Brachiopods

- Bryozoans

- Molluscs

- Polychaetes

- Serpulid tubes

- Shark eggs

- Eunicid tubes

- Tunicates

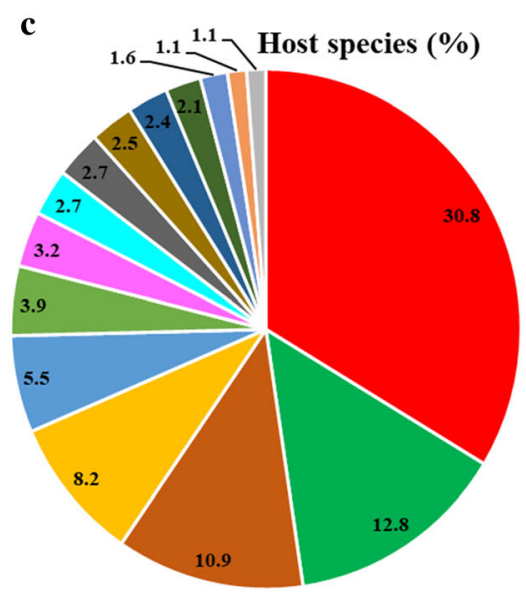

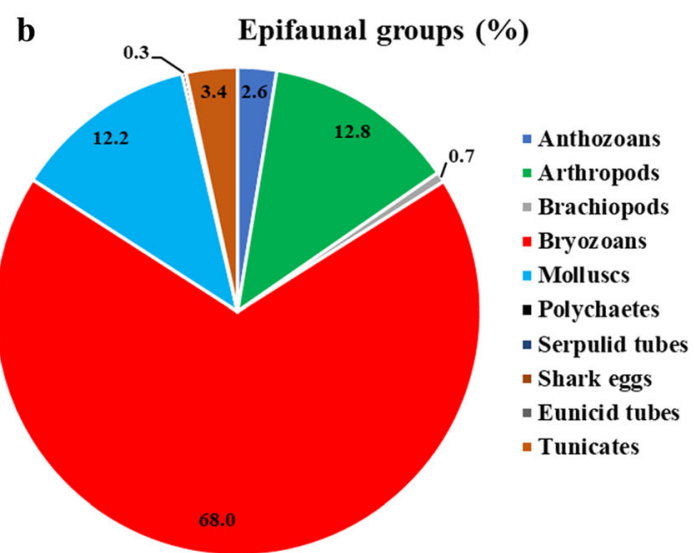

d $\left.\quad 1.4{ }^{1.0}\right]_{1.3}^{1.0}||^{1.0}$ Epifaunal species (\%)

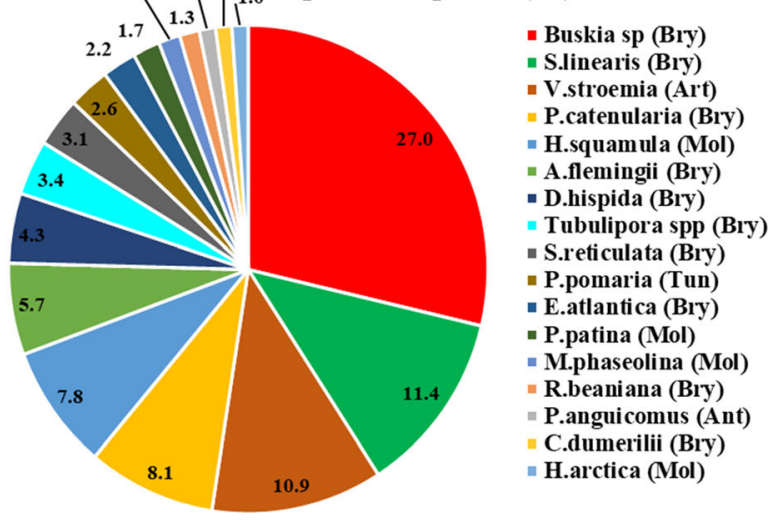

Fig. 3 Relative frequency of hosts and epifauna at the group $\mathbf{a}, \mathbf{b}$ and species $\mathbf{c}, \mathbf{d}$ levels

test (Dinno 2017). Accounting for the multiple comparisons, the $p$ values were adjusted using the Bonferroni correction (Armstrong 2014). The role of body size and morphological features in shaping the epifaunal communities was analysed through distance-based linear modelling (Clarke and Gorley 2015). The role of hosts in enhancing local biodiversity was carried out by comparing the biodiversity of hosts' epifauna (S, $H$ and d) with the biodiversity of total sessile macrofaunal communities recorded at MRC previously (Henry et al. 2010, 2013; Kazanidis et al. 2016).

\section{Results}

\section{Hosts and epifaunal species}

In total, 157 sessile macrofaunal species were identified. Out of them, 43 species were found to host epifauna (Table S1). Most of them (41 out of 43) were "alive" species and the remaining two were empty tubes belonging to families Serpulidae and Eunicidae (calcareous-tube- building \& parchment-like tube-building polychaetes, respectively). Notably, shark eggs (possibly the species Galeus melastomus) at station 1485 were hosting epifaunal species, e.g. the encrusting bryozoan Amphiblestrum flemingii (Fig. 2). Across these 43 host species, bivalves (mainly Pododemus squama and Heteranomia squamula) were the most common hosts $(\sim 47.83 \%$ of total number of associations), followed by the eunicid tubes (13.04\%), the serpulid tubes $(10.71 \%)$, bryozoans $(9.16 \%$; mainly the erect species Omalosecosa ramulosa) and tunicates (7.76\%; mainly the erect species Polycarpa pomaria) (Fig. 2; Fig. 3a--c). Regarding the epifauna, 39 species were identified (Table S2). They were dominated by bryozoans (68\%; mainly the species Schizomavella linearis, Buskia sp., Pyripora catenularia, Amphiblestrum flemingii, Disporella hispida), followed by the barnacle Verruca stroemia (12.8\%) and molluscs (12.2\%; mainly Heteranomia squamula) (Fig. 3b-d).

In terms of hosts, molluscs had significantly higher values regarding the types of host-epifauna (e.g. "Bryozoan on Mollusc" or "Mollusc on Tunicate") associations (T) $(3.25 \pm 0.55)$, the number of host-epifauna 

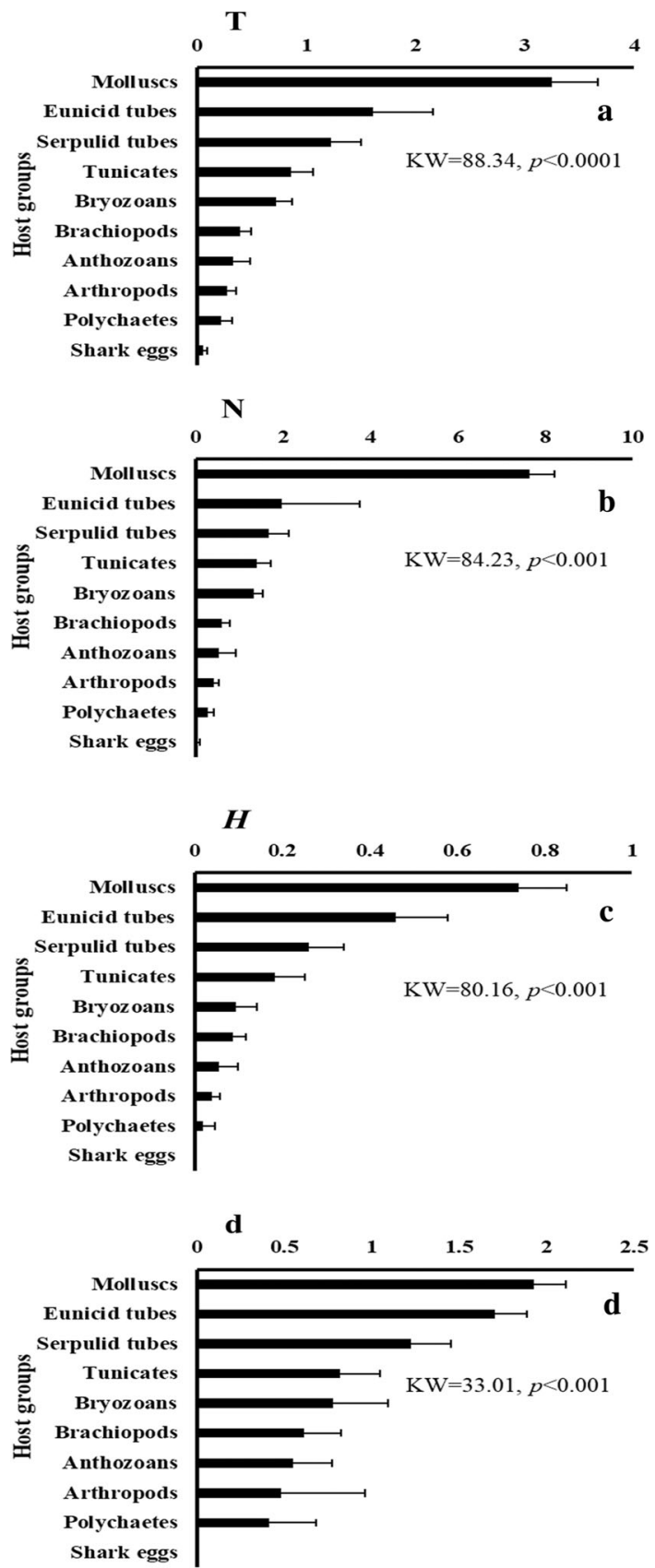

Fig. 4 Analysis of variance for the a types of host-epifauna associations (T), b number of host-epifauna associations $(\mathrm{N})$, c Shannon-Wiener index $(H)$ and d Margalef index (d) of epifaunal associations across the host groups. Average values and standard errors are given. "KW": Kruskal-Wallis test. $p$-values are given

associations $(\mathrm{N})(7.63 \pm 1.76)$ and $H(0.73 \pm 0.12)$ than all the other groups (Fig. 4; Table 2). Statistically significant differences were also found between other groups. Specifically, regarding the types of host-epifauna associations and $H$, the eunicid tubes $(1.61 \pm 0.41$ and $0.45 \pm 0.11$, respectively) and serpulid tubes $(1.22 \pm 0.27$ and $0.26 \pm 0.07)$ had significantly higher values than the anthozoans $(0.33 \pm 0.10$ and $0.05 \pm 0.03)$ and the arthropods $(0.27 \pm 0.09$ and $0.03 \pm 0.02)$. In terms of $d$, statistically significant differences were found between molluscs and arthropods $(1.70 \pm 0.18$ vs. $0.41 \pm 0.26$, respectively), eunicid tubes and arthropods (1.92 \pm 0.18 vs. $0.41 \pm 0.26)$, eunicid tubes and bryozoans $(1.92 \pm 0.18$ vs. $0.55 \pm 0.22)$ (Fig. 4 ; Table 2).

The body size and morphological features of the hosts had a statistically significant contribution $(p<0.05)$ explaining in total $32.96 \%$ of the variability in epifaunal communities. Specifically body size $(9.88 \%, p<0.01)$, body surface's texture $(8.51 \%, p<0.01)$, body orientation $(5.20 \%$, $p<0.05)$, growth form $(4.87 \%, p<0.01)$, calcification $(1.92 \%, p>0.05)$ and condition during collection $(2.54 \%$, $p>0.05$ ) (Table S4). Species with a body size at $50-99 \mathrm{~mm}^{2}$ had a statistically significant $(p<0.05)$ higher type of associations than smaller ones $\left(0-49 \mathrm{~mm}^{2}\right)$. Species with a horizontal body orientation had a higher number $(p<0.05)$ of associations than the erect ones and solitary species had statistically higher values $(p<0.05)$ for $d$ than the colonial ones (Fig. 5). It should also be mentioned that in some cases there was a marginal absence of statistically significant differences (e.g. $p=0.07$ ), but there was a clear difference in the average values between groups (e.g. for $\mathrm{N}$ and $H$ between organisms with smooth and non-smooth surfaces; Fig. 5).

\section{Types of host-epifauna associations}

In total, 101 and 339 unique types of host-epifauna associations were recorded at the group (e.g. "Bryozoan on Mollusc") (Fig. 6a; Table S5) and species levels (e.g. "Buskia sp. on Heteranomia squamula") (Fig. 6b; Table S6), respectively. Almost half of them (51.92\%) were composed of a single epifaunal species on a host. This was followed by the type where two species were attached on a host $(34.22 \%)$, three species $(8.55 \%)$, four species $(1.77 \%)$ and five species on a host $(0.88 \%)$. In a few cases (2.65\%), epifaunal species were attached on an organism which was attached on another host (e.g. the bryozoan Buskia sp. was attached on the mollusc Heteranomia squamula which was attached on an empty serpulid tube).

Fourteen types of associations ("Epifauna_Host") were quite widespread as they composed more than $70 \%$ of the number of host-epifauna associations. The most common type of association was bryozoans on molluscs (i.e. "Bryozoan_Mollusc" and Bryozoan-Bryozoan_Mollusc" "30.82\%) (Fig. 6a); specifically, "Buskia_H.squamula", "S.linearis_H.squamula" and "P.catenularia_H.squamula" were the most common associations of bryozoans on molluscs (Fig. 6b). "Bryozoan_Mollusc" association was followed by the "Bryozoan_Bryozoan" (6.92\%) and "Bryozoan_Serpulid tube" (5.35\%) (Fig. 6a).

Analyses using epifauna-host associations did not reveal almost any clustering of groups at a level of similarity 
Table 2 Pairwise comparisons for the types of host-epifauna associations (T), number of host-epifauna associations (N), Shannon-Wiener index $(H)$ and Margalef index (d) of epifaunal communities across the host groups

\begin{tabular}{|c|c|c|c|c|c|c|c|c|c|}
\hline Types of associations & ANT & ART & BRA & BRY & MOL & POL & SER & SHA & TUB \\
\hline \multicolumn{10}{|l|}{ ART } \\
\hline \multicolumn{10}{|l|}{ BRA } \\
\hline \multicolumn{10}{|l|}{ BRY } \\
\hline MOL & $-5.79 * * * *$ & $-6.05 * * * *$ & $-5.88 * * * *$ & $-3.75^{* *}$ & & & & & \\
\hline POL & & & & & $6.31 * * *$ & & & & \\
\hline SER & $-3.31 *$ & $-3.57 * *$ & $-3.39 *$ & & & $-3.82 * *$ & & & \\
\hline SHA & & & & $3.58 * *$ & $7.33 * * * *$ & & $4.85 * * * *$ & & \\
\hline TUB & & & & & $3.36^{*}$ & & & $-3.97 * *$ & \\
\hline TUN & & & & & $3.68 * *$ & & & $-3.65 * *$ & \\
\hline Number of associations & ANT & ART & BRA & BRY & MOL & POL & SER & SHA & TUB \\
\hline \multicolumn{10}{|l|}{ ART } \\
\hline \multicolumn{10}{|l|}{ BRA } \\
\hline \multicolumn{10}{|l|}{ BRY } \\
\hline MOL & $-5.70 * * * *$ & $-5.86 * * * *$ & $-5.71 * * * *$ & $-3.55 * *$ & & & & & \\
\hline POL & & & & & $6.25 * * * *$ & & & & \\
\hline SER & & $-3.26^{*}$ & & & & $-3.65^{* *}$ & & & \\
\hline SHA & & & & $3.74 * *$ & $7.29 * * * *$ & & $4.70 * * *$ & & \\
\hline TUB & & & & & $3.58 * *$ & & & $-3.71 * *$ & \\
\hline TUN & & & & & $3.55 * *$ & & & $-3.74 * *$ & \\
\hline $\begin{array}{r}H \text { of epifaunal } \\
\text { communities }\end{array}$ & ANT & ART & BRA & BRY & MOL & POL & SER & SHA & TUB \\
\hline \multicolumn{10}{|l|}{ ART } \\
\hline \multicolumn{10}{|l|}{ BRA } \\
\hline \multicolumn{10}{|l|}{ BRY } \\
\hline MOL & $-5.85 * * * *$ & $-6.07 * * * *$ & $-5.50 * * * *$ & $-5.52 * * * *$ & & & & & \\
\hline POL & & & & & $6.36 * * * *$ & & & & \\
\hline SER & & & & & $3.70 * *$ & & & & \\
\hline SHA & & & & & $6.64 * * * *$ & & & & \\
\hline TUB & $-3.57 * *$ & $-3.79 * *$ & & & & $-4.08 * *$ & & $-4.36 * * *$ & \\
\hline TUN & & & & & $4.57 * * *$ & & & & \\
\hline $\begin{array}{l}\mathrm{d} \text { of epifaunal } \\
\text { communities }\end{array}$ & ANT & ART & BRA & BRY & MOL & POL & SER & SHA & TUB \\
\hline \multicolumn{10}{|l|}{ ART } \\
\hline \multicolumn{10}{|l|}{ BRA } \\
\hline \multicolumn{10}{|l|}{ BRY } \\
\hline MOL & & $-3.22 *$ & & & & & & & \\
\hline \multicolumn{10}{|l|}{ POL } \\
\hline \multicolumn{10}{|l|}{ SER } \\
\hline \multicolumn{10}{|l|}{ SHA } \\
\hline TUB & & $-3.62 * *$ & & $-3.55^{* *}$ & & & & & \\
\hline TUN & & & & & & & & & \\
\hline
\end{tabular}

The comparisons were done using the Dunn test (DT), following the methodology in Materials and Methods. Only statistically significant results are shown. $* p<0.05 ; * * p<0.01 ; * * * p<0.001$; *****p<0.0001. ANT: Anthozoans; ART: Arthropods; BRA: Brachiopods; BRY: Bryozoans; MOL: Molluscs; POL: Polychaetes; SER: Serpulid tubes; SHA: Shark eggs; TUB: eunicid tubes

higher than $50 \%$; the only exception to that was the clustering of most bryozoan species (13 of 15) in a cluster with $\sim 60 \%$ similarity. Almost all these 13 bryozoans were encrusting forms hosting very little epifauna. The species that were among the most common hosts-i.e. the bivalves Pododesmus squama and Heteranomia squamula, 

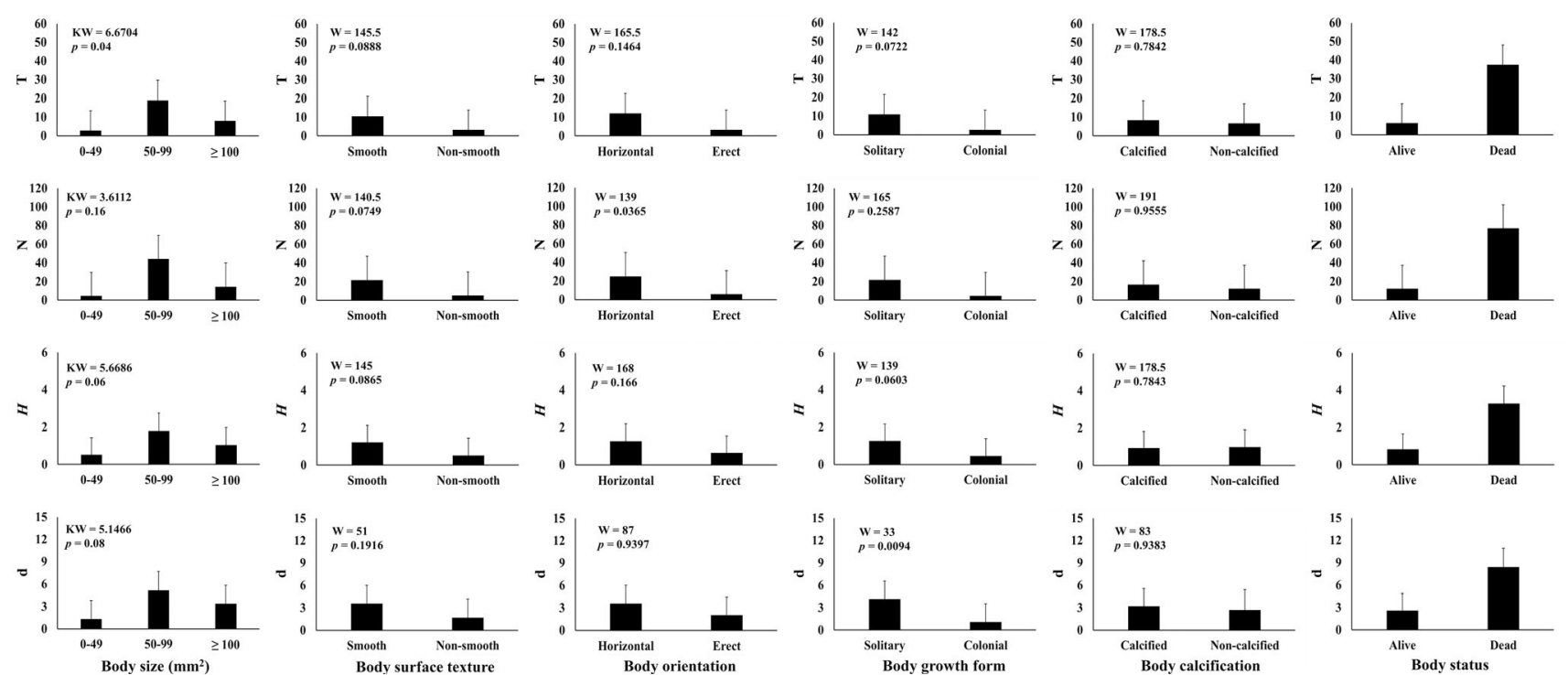

Fig. 5 Comparisons of types of associations (T), number of associations $(\mathrm{N})$, Shannon-Wiener index $(H)$ and Margalef index (d) of epifaunal communities in terms of hosts' body size (0-49, $50-99, \geq 100 \mathrm{~mm}^{2}$ ), body surface roughness (smooth, non-smooth),

body orientation (horizontal, erect), growth (solitary, colonial), body texture (calcified, non-calcified) and condition (alive, dead). Average values and standard errors are given. "W": Wilcoxon rank sum test; "KW": Kruskal-Wallis test. $p$-values are given
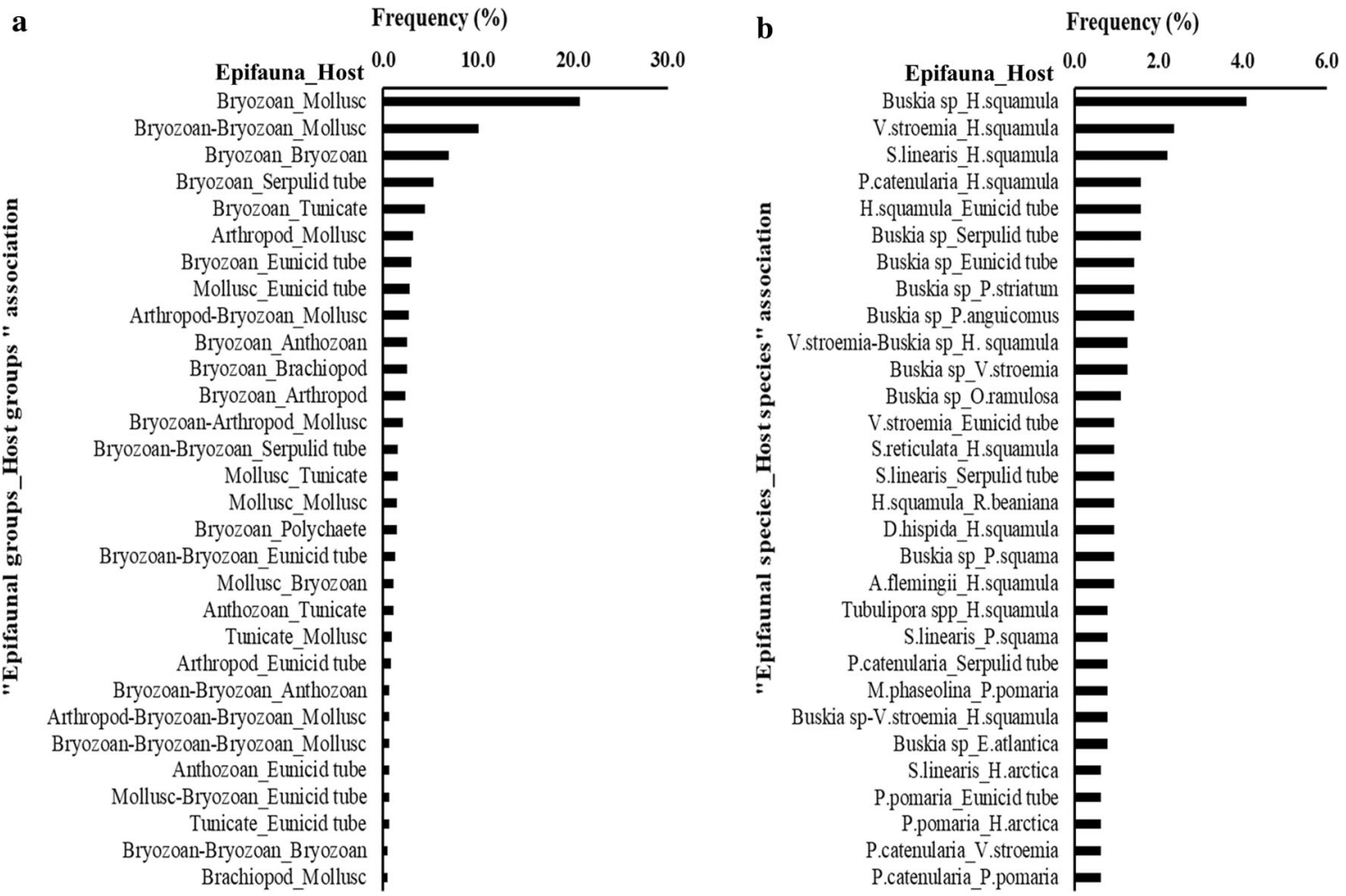

Fig. 6 Frequency of "Epifauna_Host" associations at the group a and species levels b. The 30 most frequent associations are shown. For the full list of "Epifauna_Host" associations at the group and species levels please see Tables S5 and S6

the empty eunicid and serpulid tubes and the tunicate Polycarpa pomaria - were grouped within the same cluster (Fig. 7). These were the hosts with the most diverse epifaunal communities (e.g. the $H$ index for the bivalves $H$. squamula and $P$. squama was 3.605 and 3.537 , respectively, for eunicid tubes was 3.337, for serpulid tubes 3.219 and for the ascidian P. pomaria was 2.558). 


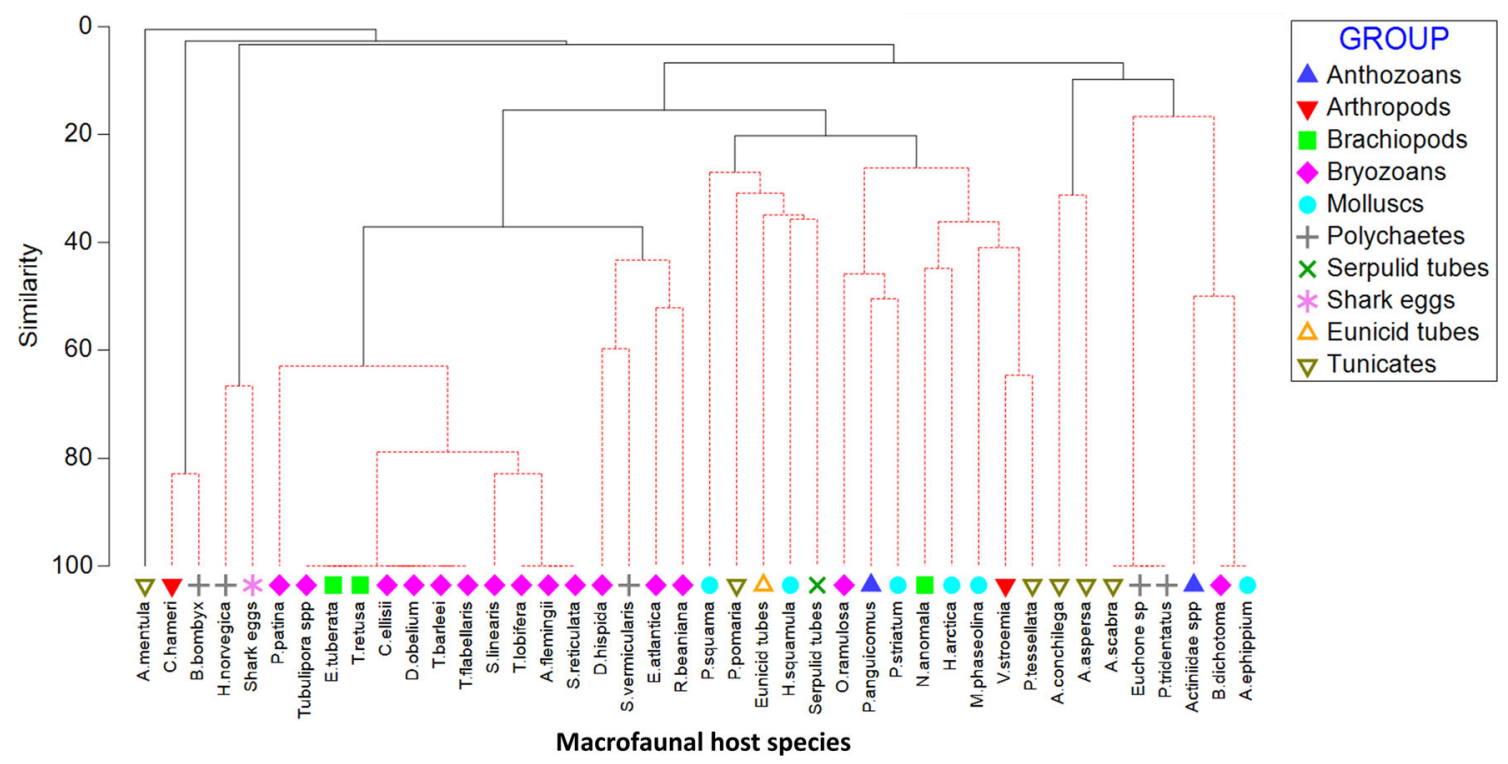

Fig. 7 Dendrogram showing the clustering of macrofaunal host species
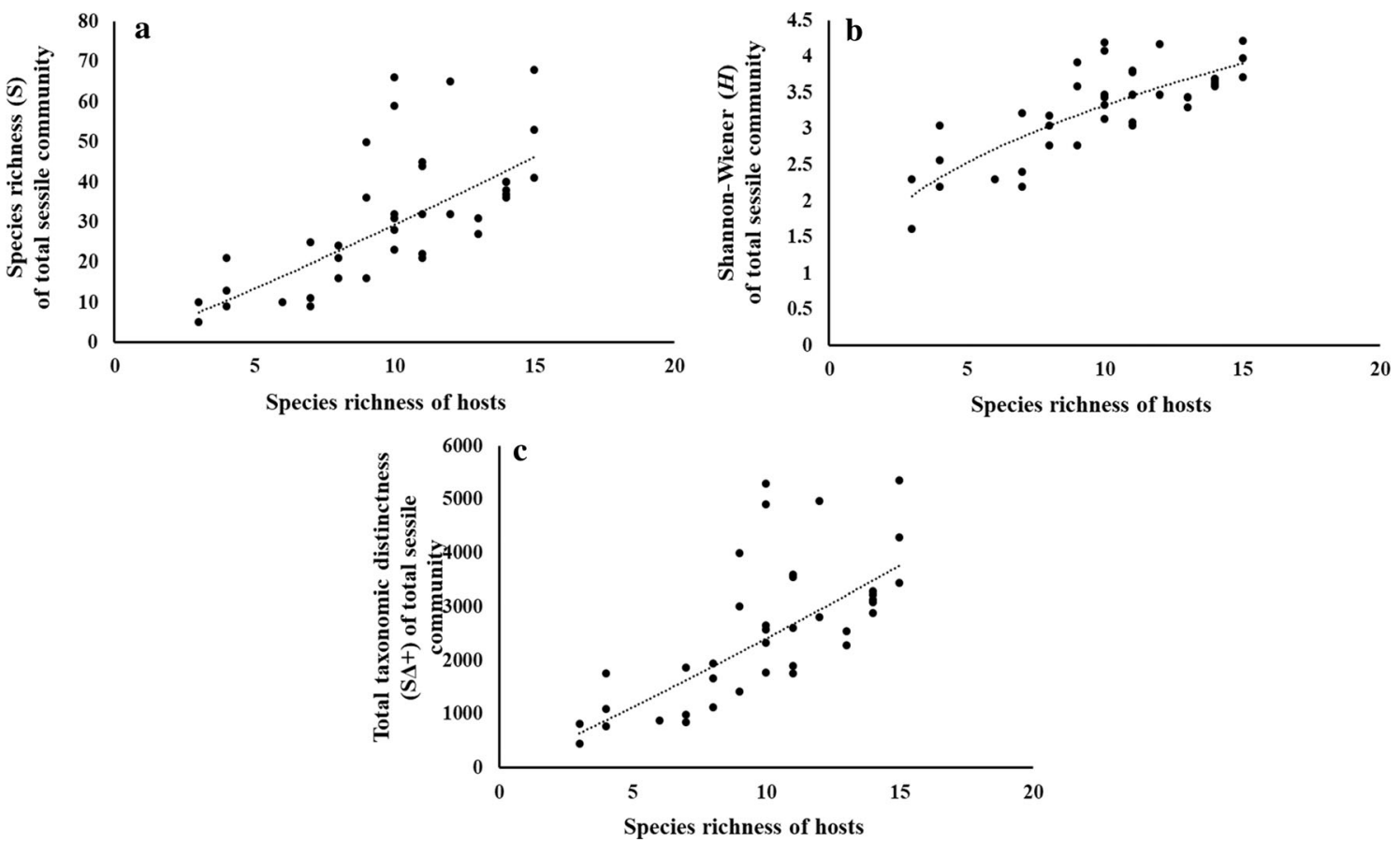

Fig. 8 Scatterplots showing the relationship between the species richness of hosts with a species richness $(S)$, b Shannon-Wiener $(H)$ and $\mathbf{c}$ total taxonomic distinctness $\left(\mathrm{S} \Delta^{+}\right)$of the total sessile macrofaunal community

The one-way ANOSIM analysis showed statistically significant differences for six pairs of host groups. These were Anthozoans vs. Bryozoans $(\mathrm{R}=0.620, p=0.02)$, Arthropods vs. Bryozoans $(\mathrm{R}=0.612, p=0.04)$, Molluscs vs. Bryozoans $(\mathrm{R}=0.586, p=0.002)$, Polychaetes vs. Bryozoans $(\mathrm{R}=0.631, p=0.001)$, Tunicates vs. Bryozoans $(\mathrm{R}=0.764, p=0.001)$ and Molluscs vs. Tunicates
( $\mathrm{R}=0.281, p=0.015$; the full list of pairs, $\mathrm{R}$ and $p$ values are shown in Table S7).

For those groups that ANOSIM showed the presence of statistically significant differences, SIMPER analyses were carried out to identify the epifaunal species driving the differences between the host groups. Specifically, SIMPER analysis revealed an average dissimilarity of 82.60 between Anthozoans and Bryozoans. The main species driving this 


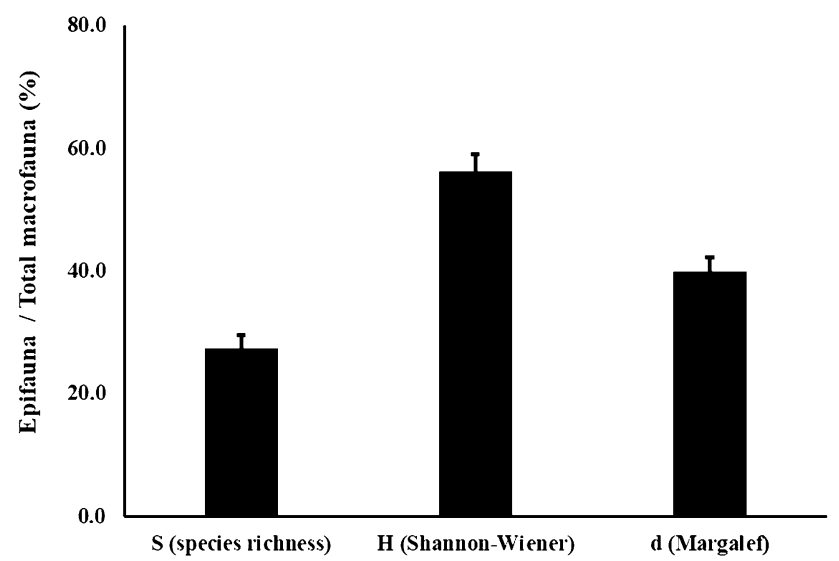

Fig. 9 Comparison (\%) of epifaunal communities attached on host species to the species richness $(S)$, Shannon-Wiener index $(H)$ and Margalef index (d) of the total sessile macrofauna

dissimilarity were the bryozoans Buskia sp., Schizomavella linearis and Plagioecia patina, all of which were more abundant in Anthozoans (Table S8). The bryozoans Buskia sp., Pyripora catenularia and the bivalve Heteranomia squamula were the species leading the average dissimilarity of 83.37 recorded between Arthropods and Bryozoans. The average dissimilarity between Bryozoans and Molluscs was 84.60; the bryozoans Buskia sp., Schizomavella linearis, Pyripora catenularia, Smittoidea reticulata and the barnacle Verruca stroemia had a cumulative contribution of $39.45 \%$. The species list explaining the dissimilarities between Bryozoans and Molluscs was much longer than those recorded in the pairs mentioned above (i.e. Anthozoans vs. Bryozoans, and Arthropods vs. Bryozoans; Table S8). The average dissimilarity between Bryozoans and Polychaetes was 89.36. This dissimilarity was attributed to the bivalve Heteranomia squamula and the bryozoans Buskia sp., Pyripora catenularia and Schizomavella linearis. These bryozoans also led the differences between Bryozoans and Tunicates (average dissimilarity 95.02) accompanied by the erect bryozoan Reteporella beaniana and Actiniaria spp. Finally, the average dissimilarity between Molluscs and Tunicates was 90.45. Dissimilarities between these two groups were attributed to a relatively long species list (Table S8) including-among other-the bryozoans Buskia sp., Schizomavella linearis, Pyripora catenularia, the erect bryozoan Reteporella beaniana, the barnacle Verruca stroemia, Actiniaria spp. and the tunicate Polycarpa pomaria.

\section{The role of hosts in enhancing local biodiversity}

The epifauna on hosts had a substantial contribution in the biodiversity of the total sessile macrofaunal communities. The relationship between the number of hosts with the richest epifaunal communities (e.g. P. squama, $H$. squamula, serpulid and eunicid tubes, $P$. pomaria) and $S, H$ and $\mathrm{S} \Delta^{+}$of the total sessile macrofaunal communities can be seen in Fig. 8. The average values of epifaunal sessile biodiversity on macrofaunal hosts compared to total sessile macrofaunal biodiversity recorded in previous studies were $27.4( \pm 2.2 \%), 56.2( \pm 2.8 \%)$ and $39.9( \pm 2.3 \%)$ for $S$, $H$ and d, respectively (Fig. 9).

\section{Discussion}

This study has shown for the first time that sessile macrofauna enhance marine hotspots' biodiversity advancing scientific knowledge about the drivers shaping enigmatic hotspots of biodiversity. It is intriguing that a rather small group of macrofauna can host up to $54.5 \%$ of the species found also attached on dead L. pertusa framework-a substrate though that has orders of magnitude higher size than sessile macrofauna (Jensen and Frederiksen 1992; Vad et al. 2017). Based on the findings of the present study, it is suggested that sessile macrofauna cause habitat cascades and enhance CWCRs biodiversity in a similar way that epiphytes increase biodiversity of tropical rainforests (Nakamura et al. 2017). The major macrofaunal species that enhance CWCRs biodiversity are either calcified themselves or closely associated with calcified organisms. This suggests that ocean acidification may have negative impacts not only on megafaunal calcified corals (Morato et al. 2020) but also on the macrofauna. The extent of these impacts on epifaunal organisms will depend on the mineralogy of the epizoan macrofauna (Smith et al. 2013; Byrne and Fitzer 2019; Ye et al. 2019), the nature of mineralization (Barclay et al. 2020; Fordyce et al. 2020; Grenier et al. 2020) and on animal physiology (Goethel et al. 2017; Diaz-Castaneda et al. 2019; Fitzer et al. 2019; Devens et al. 2020; Sokolowski et al.2020). Based on that, it is possible that climate change impacts on CWCR will be more severe than previously thought.

\section{Hosts with diverse epifaunal communities}

The bivalves Pododesmus squama, Heteranomia squamula, the tunicate Polycarpa pomaria, serpulid and eunicid tubes hosted the most diverse epifaunal communities. These observations agree with findings from shallow-water areas where mussels, oysters and serpulid polychaetes create complex biogenic habitats with high species richness (Sanderson et al. 2008).

Macrofauna hosting the most diverse epifaunal communities were species of relatively large size, horizontal and with smooth surfaces. These findings agree with previous studies which showed that the host's body size was 
positively related to epifaunal biodiversity (Buhl-Mortensen et al. 2010). Erect species hosted less diverse communities than horizontally laid ones, but the drivers behind this are not clear. Experiments with ascidians have shown higher settlement in vertical surfaces suggesting greater mortality of newly settled individuals or larvae on horizontal surfaces (Gotelli 1987), while surface orientation did not have an impact in the early growth and survivorship of scleractinian coral larvae (Babcock and Mundy 1996). The lower diversity in erect species may be related to some kind of chemical defence or to their rough/spiny surfaces hindering larvae settlement (Parisi et al. 2020). Furthermore, studies have shown that settlement is shaped by textural differences. In barnacles, the settlement was higher in fine/ medium-roughness surfaces than in coarse/smooth ones (Hills and Thomason 1998). Bryozoans seem to require a firm substratum for attachment, and many also prefer to settle on relatively smooth surfaces (McKinney and McKinney 1993).

Despite the role of hosts' body size and morphology in explaining epifaunal biodiversity, it is important to note that most of the variability remains unaccounted for. For example, there were organisms with relatively large size and smooth surfaces that hosted little epifauna (e.g. Ascidia and Ascidiella tunicates and the anthozoan P. anguicomus). There are several reasons that could explain this situation. First, it is well known that sessile invertebrates have developed mechanisms to protect themselves from biofouling, bacterial infection, and predators. Perhaps the most widespread mechanism is the production of chemically active compounds (e.g. secondary metabolites) which can be toxic for larvae and inhibit their settlement (Datta et al. 2015). A second explanation could be the presence of microbial films on the hosts with the relationships between host and biofilm varying from harmful to beneficial (Dobretsov and Rittschof 2020). Experimental studies have shown that bryozoan larvae had little success in the colonization of surfaces with bacterial biofilms probably due to bacterial extracellular materials (Maki et al. 1989). Low biodiversity on large-sized hosts with smooth surfaces may be also due to the fact that the first colonizers (e.g. encrusting bryozoans) are strong space competitors (Beaulieu 2001) and/or induce the further settlement of conspecific larvae through the production of chemical compounds (Zimmer et al. 2016). Evidence on successional dynamics is also available from the fossil record (Barclay et al. 2013; Schneider 2013). For example, studies on Carboniferous brachiopods showed that much of the spatial and temporal variation in their epibiont communities was attributed to shifts in the magnitude and selective nature of larval recruitment (Lescinsky 1997).

\section{Habitat cascade and types of host-epifauna associations}

The findings of the present study provide evidence for first time that habitat cascades known up to now mainly for forests, salt marshes, seagrass meadows, and seaweed beds (Thomsen et al. 2010), are also present in CWCRs. Here, the role of the basal habitat former is played by the $L$. pertusa framework on which intermediate habitat formers exist (e.g. the bivalves, the tunicates, the polychaete tubes examined here) that in turn create living space for the other organisms (e.g. bryozoans, brachiopods, anthozoans). Faunal associations recorded in the present study resemble closely to the type of habitat cascade seen in forests and some shallow-water ecosystems where the size of the intermediate habitat former is smaller than that of the basal habitat former (Thomsen et al. 2010). For example, at MRC Actiniidae specimens had colonized eunicid tubes (Fig. 2a) or the bryozoan Disporella hispida had colonized the brachiopod Novocrania anomala (Fig. 2b). On the contrary the presence of the type recorded in soft-bottom estuaries where a relatively small invertebrate (e.g. polychaete, bivalve) provides basal habitat for larger intermediate seaweeds that, in turn, generate habitat for focal invertebrates and epiphytes (Thomsen et al. 2010) does not seem to be the case in CWCRs.

The absence of epifaunal communities living attached on a specific taxonomic group at MRC pinpoint to the dominance of facultative relationships where the host supplies habitat to its epifauna. In their review on corals' epifauna, Buhl-Mortensen and Mortensen (2004a) mentioned that out of the 980 species found till then living on cold-water corals, 112 could be characterized as symbionts of which 30 species were obligate to various cnidarian taxa. 53\% of the obligate deep-water coral symbionts were parasites, $47 \%$ were commensals. The prevalence of facultative relationships is supported also from more recent studies on pennatulaceans in the northwest Atlantic (Baillon et al. 2014), gorgonians and sea pens in the Norwegian continental margin (Buhl-Mortensen and Mortensen 2004b), scleractinian corals in the Mediterranean Sea (Rueda et al. 2019) and North Pacific (Du Preez et al. 2020), deep-sea sponges (Kazanidis et al. 2016; Kersken et al. 2014; Hawkes et al. 2019) and fish (Milligan et al. 2016; D’Onghia 2019).

The situation described above seems to be in contrast with the current perception about tropical reefs where large number of obligate symbionts has been recorded (Fautin 1986; Stella et al. 2011; Gilpin and Chadwick 2017). The mechanisms behind this sharp difference are not clear. In their review, Buhl-Mortensen and Mortensen (2004a) provided plausible explanations about this phenomenon elaborating on the time needed for the development of 
obligate relationships, the frequency of disturbance, variability of nutrient supply and mode of larval development. On geological time scales, North Atlantic CWCRs have been subject to extensive changes leading to regional extinctions during glaciation (Dorschel et al. 2005; Frank et al. 2011). The MRC was glaciated and initiated 7-8 kya (Douarin et al. 2013). In contrast, the Mediterranean basin likely acted as a glacial refuge for cold-water corals (Henry et al. 2014). Based on this it could be expected that obligate relationships would be more prevalent in the Mediterranean than the North Atlantic.

Recent studies have shown, however, that facultative relationships are also the major pattern in Mediterranean CWCRs with a few commensal associations (Rueda et al. 2019). Variability in nutrient supply may also induce the lack of obligate relationships in CWCRs as cold-water corals and their epifauna rely on organic matter produced in upper ocean layers (Duineveled et al. 2007; Kazanidis and Witte 2016). Variability in nutrient supply may be even more pronounced in the bathyal zone than the continental shelf hindering obligate relationships in there; this suggestion is based on findings which have shown organic matter supplied to CWCRs in the continental shelf is higher in quantity and of greater quality compared to the organic matter supplied to CWCRs in the bathyal zone (Kazanidis and Witte 2016 and references therein). Another explanation offered by Buhl-Mortensen and Mortensen (2004a) was related to the direct development or very short planktonic larval development of several species associated with L. pertusa. Living in various habitats may be an adaptation for species with short larval periods to ensure successful dispersal in the long run. Scientific knowledge, however, about larval biology of organisms associated with cold-water corals is very limited (Larsson et al. 2014) and further work is needed. Here, it could also be mentioned that the limited presence of obligate relationships in CWCRs may be also due to strong currents found there (Duineveld et al. 2007; Mohn et al. 2014), which may hinder the establishment of stable associations over evolutionary timescales.

\section{Resilience of marine biodiversity hotspots in the future ocean?}

The bathyal zone where most of the CWCRs are found will suffer the most significant changes in $\mathrm{pH}$ in all oceans by 2100 (Puerta et al. 2020 and references therein). The habitat suitability for calcifying organisms in the deep sea will get severely decreased; $>80 \%$ reduction is predicted for scleractinians and octocorals (Morato et al. 2020). Research on the impacts of acidification on calcified organisms pinpoint to more fragile skeletons with greater porosity (Byrne and Fitzer 2019; Hennige et al. 2020) and altered anchoring ability of bivalves (O'Donnell et al. 2013). Furthermore, ocean warming has been shown to destabilize the microbial symbionts in corals, sponges, and bivalves increasing their susceptibility to parasites (Baker et al. 2018). This deterioration of health status can have cascading effects on the geographic distribution of organisms (Gormley et al. 2013) and habitat provision (Bell et al. 2018). These findings are alarming considering that bivalves and serpulid polychaetes (i.e. major macrofaunal habitat suppliers as shown here) are found in several CWCRs in continental margins in the North Atlantic (Jensen and Frederiksen 1992; Duineveld et al. 2007; Henry and Roberts 2007; Cordes et al. 2008; Kenchington et al. 2017) and the Mediterranean (Rueda et al. 2019), while Eunice norvegica is a ubiquitous CWCR component from tropical to boreal latitudes (OBIS 2020_obis.org).

The present study has shown that macrofaunal species enhance CWCR biodiversity through habitat supply. Most of the species, however, that enhance CWCR biodiversity are calcified themselves or live closely with calcified species (e.g. the cold-water coral L. pertusa), and thus, it is possible that their health status will be negatively affected by the impacts of climate change (e.g. ocean acidification). These findings suggest that the impacts of climate change on the structure, functioning and ultimately on the health status of CWCRs can potentially be more severe than previously thought.

Supplementary InformationThe online version contains supplementary material available at https://doi.org/10.1007/s00338021-02114-w.

Acknowledgements This study received funding from the European Union's Horizon 2020 research and innovation programme under grant agreement no. 678760 (ATLAS) and grant agreement no. 818123 (iAtlantic). This output reflects only the authors' view, and the European Union cannot be held responsible for any use that may be made of the information contained therein. The authors would like to thank the two Reviewers for their constructive comments improving the manuscript. The authors would like to thank the following taxonomists for providing valuable guidance in the identification of the specimens: Professor Emerita Daphne G. Fautin (Anthozoa), Professor Meg Daly (Anthozoa), Professor Gordon B Curry (Brachiopoda), Professor Adriannna Giangrande (Polychaeta), Professor Fabio Badalamenti (Polychaeta), Dr Tim Worsfold (Polychaeta), Dr Ruth Barnich (Polychaeta), Susan Chambers (Polychaeta), Dr Anna Holmes (Bivalvia), Dr Graham Oliver (Bivalvia), Dr Tammy Horton (Amphipoda), Dr Gretchen Lambert (Ascidiacea), Dr Jennifer Loxton (Bryozoa), Dr Christopher Mah (Asteroidea), Dr Eve C. Southward (Ophiuroidea). The authors would like also to thank Dr Johanne Vad for the creation of the map (Figure 1), Sarah Fritsch and Izzy Hassall for their help in sorting macrofauna, and finally the captains and crews of the vessels used for the collection of benthic samples.

\section{Declarations}

Conflict of interest The authors declare no conflict of interest. 
Open Access This article is licensed under a Creative Commons Attribution 4.0 International License, which permits use, sharing, adaptation, distribution and reproduction in any medium or format, as long as you give appropriate credit to the original author(s) and the source, provide a link to the Creative Commons licence, and indicate if changes were made. The images or other third party material in this article are included in the article's Creative Commons licence, unless indicated otherwise in a credit line to the material. If material is not included in the article's Creative Commons licence and your intended use is not permitted by statutory regulation or exceeds the permitted use, you will need to obtain permission directly from the copyright holder. To view a copy of this licence, visit http://creativecommons. org/licenses/by/4.0/.

\section{References}

Angiolillo M, Canese S (2017) Deep gorgonians and corals of the Mediterranean Sea. Chapter 3 - Corals in a Changing World

Armstrong R (2014) When to use the Bonferroni correction. Ophthalmic Physiol Opt 34:502-508

Babcock R, Mundy C (1996) Coral recruitment: Consequences of settlement choice for early growth and survivorship in two scleractinians. J Exp Mar Biol Ecol 206:179-201

Baillon S, Hamel J-F, Mercier A (2014) Diversity, distribution and nature of faunal associations with deep-sea pennatulacean corals in the northwest Atlantic. PLoS ONE 9(11):e111519

Barclay KM, Gingras MK, Packer ST, Leighton LR (2020) The role of gastropod shell composition and microstructure in resisting dissolution caused by ocean acidification. Mar Env Res 162:105105

Barclay KM, Schneider CL, Leighton LR (2013) Palaeoecology of Devonian sclerobionts and their brachiopod hosts from the Western Canadian sedimentary basin. Palaeogeogr Palaeoclimatol Palaeoecol 383-384:79-91

Baker DM, Freeman CJ, Wong JCY, Fogel ML, Knowlton N (2018) Climate change promotes parasitism in a coral symbiosis. ISME J 12:921-930

Beaulieu SE (2001) Life on glass houses: sponge stalk communities in the deep sea. Mar Biol 138:803-817

Bell JJ, Rovellini A, Davy SK, Taylor MW, Fulton EA, Dunn MR, Bennett HM, Kandler NM, Luter HM, Webster N (2018) Climate change alterations to ecosystem dominance: how might sponge-dominated reefs function? Ecol 99:1920-1931

Bolotov IN, Kondakov AV, Vikhrev IV, Aksenova OV, Bespalaya YV, Gofarov MY, Kolosova YS, Konopleva ES, Spitsyn VM, Tanmuangpak K, Tumpeesuwan S (2017) Ancient river inference explains exceptional oriental freshwater mussel radiations. Sci Rep 7:2135

Bourque JR, Demopoulos AWJ (2018) The influence of different deep-sea coral habitats on sediment macrofaunal community structure and function. PeerJ 6:e5276

Buhl-Mortensen L, Mortensen PB (2004a) Symbiosis in deep-water corals. Symbiosis 37:33-61

Buhl-Mortensen L, Mortensen PB (2004b) Crustaceans associated with the deep-water gorgonian corals Paragorgia arborea (L., 1758) and Primnoa resedaeformis (Gunn., 1763). J Nat Hist 38:1233-1247

Buhl-Mortensen L, Vanreusel A, Gooday AJ, Levin LA, Priede IG, Buhl-Mortensen P, Gheerardyn H, King NJ, Raes M (2010) Biological structures as a source of habitat heterogeneity and biodiversity on the deep ocean margins. Mar Ecol 31:21-50

Burk L (2018) Tadaatoolbox Package. R package version 0.16.1. https://github.com/tadaadata/tadaatoolbox
Byrne M, Fitzer S (2019) The impact of environmental acidification on the microstructure and mechanical integrity of marine invertebrate skeletons. Conserv Physiol 7:coz062

Cantonati M, Füreder L, Gerecke R, Jüttner I, Cox EJ (2012) Crenic habitats, hotspots for freshwater biodiversity conservation: toward an understanding of their ecology. Freshw Sci 31:463480

Carreiro-Silva M, Ocana O, Stankovic D, Sampaio I, Porteiro FM, Fabri M-C, Stefanni S (2017) Zoantharians (Hexacorallia: Zoantharia) associated with cold-water corals in the Azores region: new species and associations in the deep sea. Front Mar Sci $4: 88$

Cathalot C, van Oevelen D, Cox TJS, Kutti T, Lavaleye M, Duineveld G, Meysman FJR (2015) Cold-water coral reefs and adjacent sponge grounds: hot spots of benthic respiration and organic carbon cycling in the deep sea. Front Mar Sci 2:37

Clarke KR, Gorley RN (2015) PRIMER v7: User Manual/Tutorial PRIMER-E: Plymouth

Cordes E, Clark MR, Evans K, Hennige SH, Kazanidis G (2021) Subchapter 7 - Cold-water corals. United Nations $2^{\text {nd }}$ World Ocean Assessment. https://www.un.org/regularprocess/

Cordes EE, McGinley MP, Podowski EL, Becker EL, Lessard-Pilon S, Viada ST, Fisher CR (2008) Coral communities of the deep Gulf of Mexico. Deep-Sea Res I 55:777-787

Datta D, Talapatra SN, Swarnakar S (2015) Bioactive compounds from marine invertebrates for potential medicines - An overview. Int Lett Nat Sci 7:42-61

Davies AJ, Duineveld GCA, Lavaleye MSS, Bergman MJN, van Haren H, Roberts JM (2009) Downwelling and deep-water bottom currents as food supply mechanisms to the cold-water coral Lophelia pertusa (Scleractinia) at the Mingulay Reef complex. Limnol Oceanogr 54:620-629

De Clippele LH, Rovelli L, Ramiro-Sánchez B, Kazanidis G, Vad J, Turner S, Glud RN, Roberts JM (2021) Mapping cold-water coral biomass: an approach to derive ecosystem functions. Coral Reefs 40:215-231

De Clippele LH, Gafeira J, Robert K, Hennige S, Lavaleye MS, Duineveld GCA, Huvenne VAI, Roberts JM (2017) Using novel acoustic and visual mapping tools to predict the small-scale spatial distribution of live biogenic reef framework in cold-water coral habitats. Coral Reefs 36:255-268

Devens HR, Davidson PL, Deaker DJ, Smith KE, Wray GA, Byrne M (2020) Ocean acidification induces distinct transcriptomic responses across life history stages of the sea urchin Heliocidaris erythrogramma. Mol Ecol 29:4618-4636

Diaz-Castaneda V, Erin Cox T, Gazeau F, Fitzer S, Delille J, Alliouane S, Gattuso J-P (2019) J Exp Biol 222:196543

Dinno A (2017) Dunn.test Package. R package version 1.3.5. https:// cran.r-project.org/web/packages/dunn.test/dunn.test.pdf

D'Onghia G (2019) Cold-water corals as shelter, feeding and lifehistory critical habitats for fish species: ecological interactions and fishing impact. In: Orejas C., Jiménez C. (eds) Mediterranean Cold-Water Corals: Past, Present and Future. Coral Reefs of the World, vol 9. Springer, Cham.

Dobretsov S, Rittschof D (2020) Love at first taste: induction of larval settlement by marine microbes. Int J Mol Sci 21:1-19

Dorschel B, Hebbeln D, Rüggeberg A, Dull W-C, Freiwald A (2005) Growth and erosion of a cold-water coral covered carbonate mound in the Northeast Atlantic during the Late Pleistocene and Holocene. Earth Planet Sci Lett 233:33-44

Douarin M, Elliot M, Noble SR, Sinclair D, Henry L-A, Long D, Moreton SG, Roberts JM (2013) Growth of north-east Atlantic cold-water coral reefs and mounds during the Holocene: A high resolution U-series and ${ }^{14} \mathrm{C}$ chronology. Earth Planet Sci Lett 375:176-187 
Douarin M, Sinclair DJ, Elliot M, Henry L-A, Long D, Mitchison F, Roberts JM (2014) Changes in fossil assemblage in sediment cores from Mingulay Reef Complex (NE Atlantic): Implications for coral reef build-up. Deep Sea Res Part II 99:286-296. https:// doi.org/10.1016/j.dsr2.2013.07.022

Douarin M, Elliott M, Noble SR, Moreton SG, Long D, Sinclair D, Henry L-A, Roberts JM (2016) North Atlantic ecosystem sensitivity to Holocene shifts in Meridional Overturning Circulation. Geophys Res Lett 43:291-298. https://doi.org/10.1002/ 2015GL065999

Duineveld GCA, Lavaleye MSS, Bergman MJN, de Stigter H, Mienis F (2007) Trophic structure of a cold-water coral mound community (Rockall Bank, NE Atlantic) in relation to the near-bottom particle supply and current regime. Bull Mar Sci 81:449-467

Duineveld GCA, Jeffreys RM, Lavaleye MSS, Davies AJ, Bergman MJN, Watmough T, Witbaard R (2012) Spatial and tidal variation in food supply to shallow cold-water coral reefs of the Mingulay Reef complex (Outer Hebrides, Scotland). Mar Ecol Prog Ser 444:97-115

Du Preez C, Swan KD, Curtis JMR (2020) Cold-water corals and other vulnerable biological structures on a North Pacific seamount after half a century of fishing. Front Mar Sci 7:17

Fautin DG (1986) Why do anemonefishes inhabit only some host actinians? Environ Biol Fish 15:171-180

Fitzer SC, McGill RAR, Gabarda ST, Hughes B, Dove M, O'Connor W, Byrne M (2019) Selectively bred oysters can alter their biomineralization pathways, promoting resilience to environmental acidification. Glob Change Biol 25:4105-4115

Fordyce AJ, Knuefing L, Ainsworth TD, Beeching L, Turner M, Leggat W (2020) Understanding decay in marine calcifiers: Micro-CT analysis of skeletal structures provides insight into the impacts of a changing climate in marine ecosystems. Methods Ecol Evol 11:1021-1041

Frank N, Freiwald A, López Correa M, Wienberg C, Eisele M, Hebbeln D, Van Rooij D, Henriet J-P, Colin C, van Weering T, de Haas H, Buhl-Mortensen P, Roberts JM, DeMol B, Douville E, Blamart D, Hatté C (2011) Northeastern Atlantic cold-water coral reefs and climate. Geol 39:743-746

Gage JD, Tyler PA (1991) Deep-Sea Biology. A natural history of organisms at the deep-sea floor. Cambridge University Press.

Gilpin JA, Chadwick NE (2017) Life-history traits and population structure of pederson cleaner shrimps Ancylomenes pedersoni. Biol Bull 233:190-205

Goethel CL, Grebmeier JM, Cooper LW, Miller TJ (2017) Implications of ocean acidification in the Pacific Arctic: Experimental responses of three Arctic bivalves to decreased $\mathrm{pH}$ and food availability. Deep Sea Res II 144:112-124

Gormley KSG, Porter JS, Bell MC, Hull AD, Sanderson WG (2013) Predictive habitat modelling as a tool to assess the change in distribution and extent of an OSPAR Priority Habitat under an increased ocean temperature scenario: consequences for Marine Protected Area networks and management. PLoS ONE 8(7):e68263

Gotelli NJ (1987) Spatial and temporal patterns of reproduction, larval settlement, and recruitment of the compound ascidian Aplidium stellatum. Mar Biol 94:45-51

Grassle JF, Maciolek NJ (1992) Deep-sea species richness: regional and local diversity estimates from quantitative bottom samples. Am Nat 139:313-341

Grenier C, Roman R, Duarte C, Navarro JM, Rodriguez-Navarro AB, Ramajo L (2020) The combined effects of salinity and $\mathrm{pH}$ on shell biomineralization of the edible mussel Mytilus chilensis. Env Poll 263:114555

Hawkes N, Korabik M, Beazley L, Tore Rapp H, Xavier JR, Kenchington E (2019) Glass sponge grounds on the Scotian
Shelf and their associated biodiversity. Mar Ecol Prog Ser 614:91-109

Hennige SJ, Wolfram U, Wickes L, Murray F, Roberts JM, Kamenos NA, Schofield S, Groetsch A, Spiesz EM, Aubin-Tam M-E, Etnoyer PJ (2020) Crumbling reefs and cold-water coral habitat loss in a future ocean: evidence of "coralporosis" as an indicator of habitat integrity. Front Mar Sci 7:668

Henry L-A, Roberts JM (2007) Biodiversity and ecological composition of macrobenthos on cold-water coral mounds and adjacent off-mound habitat in the bathyal Porcupine Seabight, NE Atlantic. Deep Sea Res I 54:654-672

Henry L-A, Davies AJ, Roberts JM (2010) Beta diversity of coldwater coral reef communities off western Scotland. Coral Reefs 29:427-436

Henry L-A, Moreno Navas J, Roberts JM (2013) Multi-scale interactions between local hydrography, seabed topography, and community assembly on cold-water coral reefs. Biogeosci 10:2737-2746

Henry L-A, Frank N, Hebbeln D, Wienberg C, Robinson L, van de Flierdt T, Dahl M, Douarin M, Morrison CL, Lopez Correa M, Rogers AD, Ruckelshausen M, Roberts JM (2014) Global ocean conveyor lowers extinction risk in the deep sea. Deep Sea Res I 88:8-16

Henry L-A, Roberts LM (2017) Global biodiversity in cold-water coral reef ecosystems. In: Rossi S, Bramanti L, Gori A, Orejas C (eds) Marine Animal Forests: The Ecology of Benthic Biodiversity Hotspots. Springer International Publishing, pp 1-21

Hills JM, Thomason JC (1998) The effect of scales of surface roughness on the settlement of barnacle (Semibalanus balanoides) cyprids. Biofouling 12:57-69

Igea J, Tanentzap AJ (2019) Multiple macroevolutionary routes to becoming a biodiversity hotspot. Sci Adv 5:eaau8067

Janas U, Burska D, Kendzlerska H, Pryputniewicz-Flis D, ŁukawskaMatuszewska K (2019) Importance of benthic macrofauna and coastal biotopes for ecosystem functioning - Oxygen and nutrient fluxes in the coastal zone. Estuar Coast Shelf Sci 225:106238.

Jensen A, Frederiksen R (1992) The fauna associated with the bank forming deepwater coral Lophelia pertusa (Scleractinaria) on the Faroe shelf. Sarsia 77:53-69

Johnson C, Inall M, Häkkinen S (2013) Declining nutrient concentrations in the northeast Atlantic as a result of a weakening Subpolar Gyre. Deep Sea Res I 82:95-107

Kazanidis G, Orejas C, Borja A, Kenchington E, Henry L-A, Callery O, Carreiro-Silva M, Egilsdottir H, Giacomello E, Grehan A, Menot L, Morato T, Ragnarsson SA, Rueda JL, Stirling D, Stratmann T, van Oevelen D, Palialexis A, Johnson D, Roberts JM (2020) Assessing the environmental status of selected North Atlantic deep-sea ecosystems. Ecol Indic 119:106624

Kazanidis G, Henry L-A, Roberts JM, Witte UFM (2016) Biodiversity of Spongosorites coralliophaga (Stephens, 1915) on coral rubble at two contrasting cold-water coral reef settings. Coral Reefs 35:193-208

Kazanidis G, Witte UFM (2016) The trophic structure of Spongosorites coralliophaga-coral rubble communities at two northeast Atlantic cold water coral reefs. Mar Biol Res 12:932-947

Kenchington E, Yashayaev I, Tendal OS, Jørgensbye H (2017) Water mass characteristics and associated fauna of a recently discovered Lophelia pertusa (Scleractinia: Anthozoa) reef in Greenlandic waters. Polar Biol 40:321-337

Kersken D, Göcke C, Brandt A, Lejzerowicz F, Schwabe E, Seefeldt MA, Veit-Köhler G, Janussen D (2014) The infauna of three widely distributed sponge species (Hexactinellida and Demospongiae) from the deep Ekström Shelf in the Weddell Sea, Antarctica. Deep Sea Res II 108:101-112 
Larsson AI, Järnegren J, Strömberg SM, Dahl MP, Lundälv T, Brooke S (2014) Embryogenesis and Larval Biology of the Cold-Water Coral Lophelia pertusa. PLoS ONE 9(7):e102222

Lescinsky HL (1997) Epibiont communities: recruitment and competition on North American carboniferous brachiopods. J Paleont 71:34-53

Li J, Wang P (2019) Discovery of deep-water bamboo coral foster in the south China Sea. Sci Rep 9:15453

Maki JS, Rittschof D, Schmidt AR, Snyder AG, Mitchell R (1989) Factors controlling attachment of bryozoan larvae: a comparison of bacterial films and unfilmed surfaces. Biol Bull 177:295-302

FK, McKinney MJ (1993) Larval behaviour and choice of settlement site: Correlation with environmental distribution pattern in an erect bryozoan. Facies 29:119-131

Milligan RJ, Spence G, Roberts JM, Bailey DM (2016) Fish communities associated with cold-water corals vary with depth and substratum type. Deep Sea Res I 114:43-54

Mohn C, Rengstorf A, White M, Duineveld G, Mienis F, Soetaert K, Grehan A (2014) Linking benthic hydrodynamics and cold-water coral occurrences: A high-resolutionmodel study at three coldwater coral provinces in the NE Atlantic. Prog Oceanogr 122:92-104

Morato T, González-Irusta J-M, Dominguez-Carrió C, Wei C-L, Davies A, Sweetman AK, Taranto GH, Beazley L, GarcíaAlegre A, Grehan A, Laffargue P, Murillo FJ, Sacau M, Vaz S, Kenchington E, Arnaud-Haond S, Callery O, Chimienti G, Cordes E, Egilsdottir H, Freieald A, Gasbarro R, GutiérrezZárate C, Gianni M, Gilkinson K, Wareham Hayes V, Hebbeln D, Hedges K, Henry L-A, Johnson D, Koen-Alonso M, Lirette C, Mastrototaro F, Menot L, Molodtsova T, Muñoz PD, Orejas C, Pennino MG, Puerta P, Ragnarsson SA, Ramiro-Sánchez B, Rice J, Rivera J, Roberts JM, Ros SW, Rueda JL, Sampaio I, Snelgrove P, Stirling D, Treble MA, Urra J, Vad J, van Oevelen D, Watling L, Walkusz W, Wienberg C, Woillez M, Levin LA, Carreiro-Silva M (2020) Climate-induced changes in the suitable habitat of cold-water corals and commercially important deep-sea fishes in the North Atlantic. Glob Chang Biol 26:2181-2202

Nakamura A, Kitching RL, Cao M, Creedy TJ, Fayle TM, Freiberg M, Hewitt CN, Itioka T, Pin Koh L, Ma K, Malhi Y, Mitchell A, Novotny V, Ozanne CMP, Song L, Wang H, Ashton LA (2017) Forests and their canopies: achievements and horizons in canopy science. Trends Ecol Evol 32:438-451

Ocean Biodiversity Information System (2020). https://obis.org/

O'Donnell MJ, George MN, Carrington E (2013) Mussel byssus attachment weakened by ocean acidification. Nat Clim Chang 3:587-590

Parisi MG, Parrinello D, Stabili L, Cammarata M (2020) Cnidarian immunity and the repertoire of defense mechanisms in anthozoans. Biol 9:283

Porter M, Dale AC, Jones S, Siemering B, Inall ME (2018) Crossslope flow in the Atlantic Inflow Current driven by the on-shelf deflection of a slope current. Deep Sea Res I 140:173-185

Puerta P, Johnson C, Carreiro-Silva M, Henry L-A, Kenchington E, Morato T, Kazanidis G, Rueda JL, Urra J, Ross S, Wei C-L, González-Irusta JM, Arnaud-Haond S, Orejas C (2020) Influence of water masses on the biodiversity and biogeography of deepsea benthic ecosystems in the North Atlantic. Front Mar Sci $7: 239$

Roberts JM, Brown CJ, Long D, Bates CR (2005) Acoustic mapping using a multibeam echosounder reveals cold-water coral reefs and surrounding habitats. Coral Reefs 24:654-669
Roberts JM, Davies AJ, Henry L-A, Dodds LA, Duineveld GCA, Lavaleye MSS, Maier C, van Soest RWM, Bergman MJN, Huhnerbach V, Huvenne VAI, Sinclair DJ, Watmough T, Long D, Green SL, van Haren H (2009) Mingulay reef complex: an interdisciplinary study of cold-water coral habitat, hydrography and biodiversity. Mar Ecol Prog Ser 397:139-151

Roberts JM, Wheeler AJ, Freiwald A (2006) Reefs of the deep: the biology and geology of cold-water coral ecosystems. Sci 312:543-547

Rueda JL, Urra J, Aguilar R, Angeletti L, Bo M, García-Ruiz C, González-Duarte MM, López E, Madurell T, Maldonado M, Mateo-Ramírez A, Megina C, Moreira J, Moya F, Ramalho LV, Rosso A, Sitjà C, Taviani M (2019) Cold-water associated fauna in the Mediterranean Sea and Adjacent areas. In: Orejas C, Jiménez C (eds) Mediterranean Cold-Water Corals: Past, Present and Future, Coral Reefs of the World 9. Springer, pp 295-333

Sanderson WG, Holt RHF, Kay L, Ramsay K, Perrins J, McMath AJ, Rees EIS (2008) Small-scale variation within a Modiolus modiolus (Mollusca: Bivalvia) reef in the Irish Sea. II. Epifauna recorded by divers and cameras. J Mar Biol Assoc UK $88: 143-149$

Schneider CL (2013) Epibiosis across the Late Devonian biotic crisis: A review. Proc Geol SSOC 124:893-909

Smith AM, Riedi MA, Winter DJ (2013) Temperate reefs in a changing ocean: skeletal carbonate mineralogy of serpulids. Mar Bio 160:2281-2294

Sokolowski A, Brulinska D, Sokolowska E (2020) Multimarker response of the ragworm Hediste diversicolor (Polychaeta) to seawater acidification derived from potential $\mathrm{CO}_{2}$ leakage from the CCS sub-seabed storage site in the Baltic Sea. J Exp Mar Biol Ecol 530-531:151433

Stella JS, Pratchett MS, Hutchings PA, Jones GP (2011) Coralassociated invertebrates: diversity, ecological importance and vulnerability to disturbance. Oceanogr Mar Biol Ann Rev 49:43-304

Sullivan MJP, Talbot J, Lewis SL, Phillips OL, Qie L,...Zemagho L (2017) Diversity and carbon storage across the tropical forest biome. Sci Rep 7:39102. https://doi.org/10.1038/srep39102

Thomsen MS, Wernberg T, Altieri A, Tuya F, Gulbransen D, McGlathery KJ, Holmer M, Silliman BR (2010) Habitat cascades: the conceptual context and global relevance of facilitation cascades via habitat formation and modification. Integr Comp Biol 50:158-175

Vad J, Orejas C, Moreno-Navas J, Findlay HS, Roberts JM (2017) Assessing the living and dead proportions of cold-water coral colonies: implications for deep-water Marine Protected Area monitoring in a changing ocean. PeerJ 5:e3705

Ye F, Jurikova H, Angiolini L, Brand U, Crippa G, Henkel D, Laudien J, Hiebenthal C, Smajgl D (2019) Variation in brachiopod microstructure and isotope geochemistry under low-pH-ocean acidification conditions. Biogeosci 16: 617-642

Zimmer RK, Ferrier GA, Kim SJ, Kaddis CS, Zimmer CA, Loo JA (2016) A multifunctional chemical cue drives opposing demographic processes and structures ecological communities. Ecol 97:2232-2239

Publisher's Note Springer Nature remains neutral with regard to jurisdictional claims in published maps and institutional affiliations. 